\title{
Pearsons Correlation and Swot Analysis of Growth of Women Entrepreneurs in Dar Es Salaam Tanzania
}

\author{
Masese Chuma Benard \\ Lecturer, Department of Computer Studies \\ Kampala International UniversityDar es Salaam College- Tanzania \\ +255659615824 Email:benasongs@gmail.com
}

\section{Dr. Nelson Jagero}

Senior Lecturer School of Post Graduate Studies and Research Kampala International University Dar es Salaam Constituent Collage.

E mail Address: jagero66@yahoo.com

\section{Basweti Ogachi Kevin}

Lecturer faculty of science and technology, Kampala international University, Dar Es Salaam Tanzania +254-787885460, +255-659615825 E-mail; kenogachi@yahoo.com

\section{Dr. Martin Onsiro Ronald}

Lecturer faculty of development studies and Business, Kampala international University, Dar Es Salaam Tanzania, +255-714887832, E-mail;onsiro2k@gmail.com

\section{Doi:10.5901/mjss.2013.v4n2p505}

\section{Abstract}

Well-functioning business sectors are crucial driving forces for economic growth. In developing countries, entrepreneurship can function as a tool to fight poverty as well as to strengthen the role of women and promote gender equality. This study used the sample size of 132 women entrepreneurs from the three districts in Dar es Salaam city; Simple random sampling was used in sampling the women entrepreneurs in Dar es Salaam city in Tanzania. A Pearson's correlation was employed in this study. SPSSv16.0 software was used to generate thePearson's correlation coefficient. The findingshowever reflected as, there is a correlation between threats and weakness is at Pearson's correlation coefficient (r) equals .421 ${ }^{* *}$ correlation is significant at the 0.01 level (2-tailed) and $p<.000$, opportunities and weakness Pearson's correlation coefficient ( $r$ ) equals . $388^{* *}$, correlation is significant at the 0.01 level (2-tailed) and $p<.000$, strengths and opportunities Pearson's correlation coefficient (r) equals $.245^{* *}$, correlation is significant at the 0.01 level (2-tailed), $\quad p<0.05$ on the other hand there was weak correlation between strengths and weakness, Pearson's correlation coefficient ( $r$ ) equals $.089, p<.309$ which indicates that the coefficient is significantly where the $(r)$ is lower than the $P$ value. Strengths and threats Pearson's correlation coefficient ( $r$ ) equals .038, indicating that there is a weak relationship in terms of correlation. $p<.667$. We can conclude that there is a correlation between weakness and threats, opportunities and weakness, strengths and opportunities. There is a weak correlation between opportunities and threats, strengths and threats.Recommendations that the government and Non-governmental organizations should open training programmes for women entrepreneurs based on their needs. Finance be made available to enable them to access business development and other services.

Key words: Pearson's correlation, SWORT Analysis, women entrepreneurs, Dar Es Salaam 


\section{Introduction}

A correlation is a measure of the strength of the linear relationship between two measurable variables. The Pearson correlation coefficient, represented as $r$, gives the strength and direction of this relationship. The closer $r$ is to 1 or to -1 then the stronger the linear relationship between the two variables. In data analysis, the association of two or more variables is often of interest (e.g. the association between strengths, weakness, opportunities and threats). Researchers are often interested in whether the variables of interest are related and, if so, how strong the association is. Different measures of association are also frequent topics in methodological research.

Correlation quantifies the extent to which two quantitative variables, $X$ and $Y$, "go together." When high values of $X$ are associated with high values of $Y$, a positive correlation exists. When high values of $X$ are associated with low values of $Y$, a negative correlation exists.

Participation of women in the economy is the real barometer of women empowerment in any society. Education and training of women play a key role for women development and empowerment. Research on developed economies has identified a potential problem when it comes to women's entrepreneurship: highly educated women seem to choose other career options than self-employment and entrepreneurship (OECD, 2004).

The lack of role models in entrepreneurship is one of the many obstacles for women entrepreneurs. There exists a strong connection between the presence of role models and the emergence of entrepreneurs (Shapero and Sokol, 1982). Women historically have not been present as entrepreneurs in general and consequently have lacked close role models. The influence of role models is gender related. That is, an individual will be more influenced by another individual of the same sex, as one's aspirations and choices tend to be more influenced by persons of the same sex (Deaux and Lafrance, 1998). Lack of awareness and experience among women is another obstacle. All stages in entrepreneurship development are dependent on relevant experience, from the identification of opportunities to the execution of running a business. The access to information is vital in this information age and only those people will survive in this highly competitive world who are informed and groomed to handle information to make appropriate decisions.

Another recurring obstacle for women to engage in entrepreneurship is the perceived lack of time or competing demands on time. Because women are responsible for so many different domestic chores and the raising of children, they do not have enough free time to develop either their entrepreneurial skills to become entrepreneurs or to develop an existing business. The lack of free time does not allow them time to travel to institutions, banks and other finance houses for advice and information on credit, to attend training programs to acquire skills, or to seek out better customers or suppliers. This lack of free time has been observed in a number of studies across different countries: for example Bangladesh (Karim, 2000), Côte d'Ivoire, Ethiopia, Mali, Morocco, Senegal and Zimbabwe (De Groot, 2001), or Sweden (Holmquistet al., 2002). The results suggest that lack of time is a barrier for most women, in most economies, independent of the level of development.

Lack of relevant networks and of societal position for women is another impediment. Women have in general a lower social position than men, which affects the kind of networks they can access or participate. There is evidence to prove that women are less involved in networks than men are, and their type of network is different. For business, it is as important to have weak-tie networks as strong ties (Aldrich and Zimmer,1986; Burt,2000; Granovetter,1985; Granovetter,1973). The strong and personal networks that women traditionally engage in are well suited to purposes linked to the family related tasks that may prove to be a hindrance in the marketplace (Lin, 1999). Thus, women differ from men in the kind of networks they use and in the social capital available to them through the network. Women have therefore less access to critical resources, support and information needed to successfully start and manage a new firm compared to men.

\section{Literature review}

Drawing on institutional theory, Baugh, Chua and Neupert (2006) discuss how the normative context affects women's participation in entrepreneurship in a number of industrialized and transition economies. They show that the relation between female entrepreneurs in a country is not connected to the level of welfare, but instead that cultural norms and values affect the proportion of women-owned businesses in a country. These norms and values are related to the general support systems towards entrepreneurship, but also to the level of gender equality in that country. They state that the institutional context, and the preconditions it creates for female entrepreneurs, is of great importance, because it affects the kind of support that will be available for individual women (Baugh, Chua andNeupert 2006). 
According to Gibb (1993) social factors may involve personal background, family background, stage of career, early life experiences and growth environment. Hebert et al. (1997) suggest that in certain contexts women may be more strongly driven by social pressures. Kirk and Belovics (2006) summarized that women become entrepreneurs in order to balance work and family. Social networks have also been identified as one of the major factors that motivate women entrepreneurs (Gadar andYunus, 2009).

Cromie (1987) found that in their motives whether or not to become an entrepreneur, women are less concerned with making money and often choose entrepreneurship as a result of career dissatisfaction. They also see entrepreneurship as a means of simultaneously satisfying their own career needs and those of their children and family. In addition the desire for greater flexibility, seeking challenges and escaping from organizational bureaucracy are also among the motivational factors that lead women to start up their own businesses (Lee andRogoff, 1997). Innovativeness, risk taking propensity and perseverance are found to have significant influence on women entrepreneurs (Nelson and Cengiz, 2005). According to studies done by Schwartz (1976), Scott (1986) and Hisrich (1986), major motivations for women to start a business were the need to achieve, the desire to control and be independent, the need for job satisfaction and economic necessity.

Entrepreneurial activity arises from different circumstances and motives that drive the decision to start a business. The decision to become self-employed may stem from the push effect of (the threat of) unemployment, but also from pull effects induced by a thriving economy producing entrepreneurial opportunities. Opportunity-based entrepreneurship involves those who choose to start their own business by taking advantage of an entrepreneurial opportunity. Necessitybased entrepreneurship involves people who start a business because other employment options are either absent or unsatisfactory (Bhola et al., 2006). Generally, the opportunity entrepreneurs are more prevalent in high-income countries, while necessity entrepreneurs are more common in the low-income countries (Reynolds et al., 2002).

\section{Methodology}

\subsection{Research design}

This paper used the Pearson correlation since the questionnaires were employed to collect primary data from the field. The survey targeted Women Entrepreneurs from the Dar es Salaam city of Tanzania, who are registered with the Tanzania Chamber of Commerce. To capture the responses of these individuals, a structured questionnaire was prepared, which was aimed to be administered to this entire population.

\subsection{Sample size}

The exercise produced a response of 132 completed questionnaires. Although we tried to contact each of the 151 women on the list, all the respondents were visited in their business ventures. Out of the remaining 19, 8 respondents did not complete filling the questionnaires, 11 of women entrepreneurs were defunct.

Table 1: Sample of women entrepreneurs in Dar es Salaam city

\begin{tabular}{lcc} 
Area & no & $\%$ \\
\hline Kinondoni & 48 & 36.92 \\
Ilala & 43 & 32.31 \\
Temeke & 41 & 30.77 \\
Total & 132 & 100.00 \\
\hline
\end{tabular}

Source: field data(2012)

\subsection{Sampling procedure}

Simple random sampling was used in sampling the women entrepreneurs in Dar es Salaam city in Tanzania. The aim of using simple random sample was to reduce the potential for human bias in the selection of cases to be included in the sample. As a result, the simple random sample provided us with a sample that was highly representative of the 
population being studied, assuming that there is limited missing data. Since the units selected for inclusion in the sample are chosen using probabilistic methods, simple random sampling allows us to make generalisations(i.e. statistical inferences) from the sampleto the population. This is a major advantage because such generalisations are more likely to be considered to have external validity.

\subsection{Data analysis}

The questionnaire were close-ended questions, using the likent scale of 5.0 strongly agree, 4.0 agree, 3.0 neutrial, 2.0 disagree, 1.0 strongly disagree. Face validity of the questionnaire was performed to ensure the relevance of content and interpretation by discussing with experienced faculty members of kampala international University.

A Pearson's correlation analysis was made, comprising the generation of correlation between strengths, weakness, opportunities and threats. SPSSv16.0 software was used to generate the Pearson's correlation.

\section{Result and Discussion}

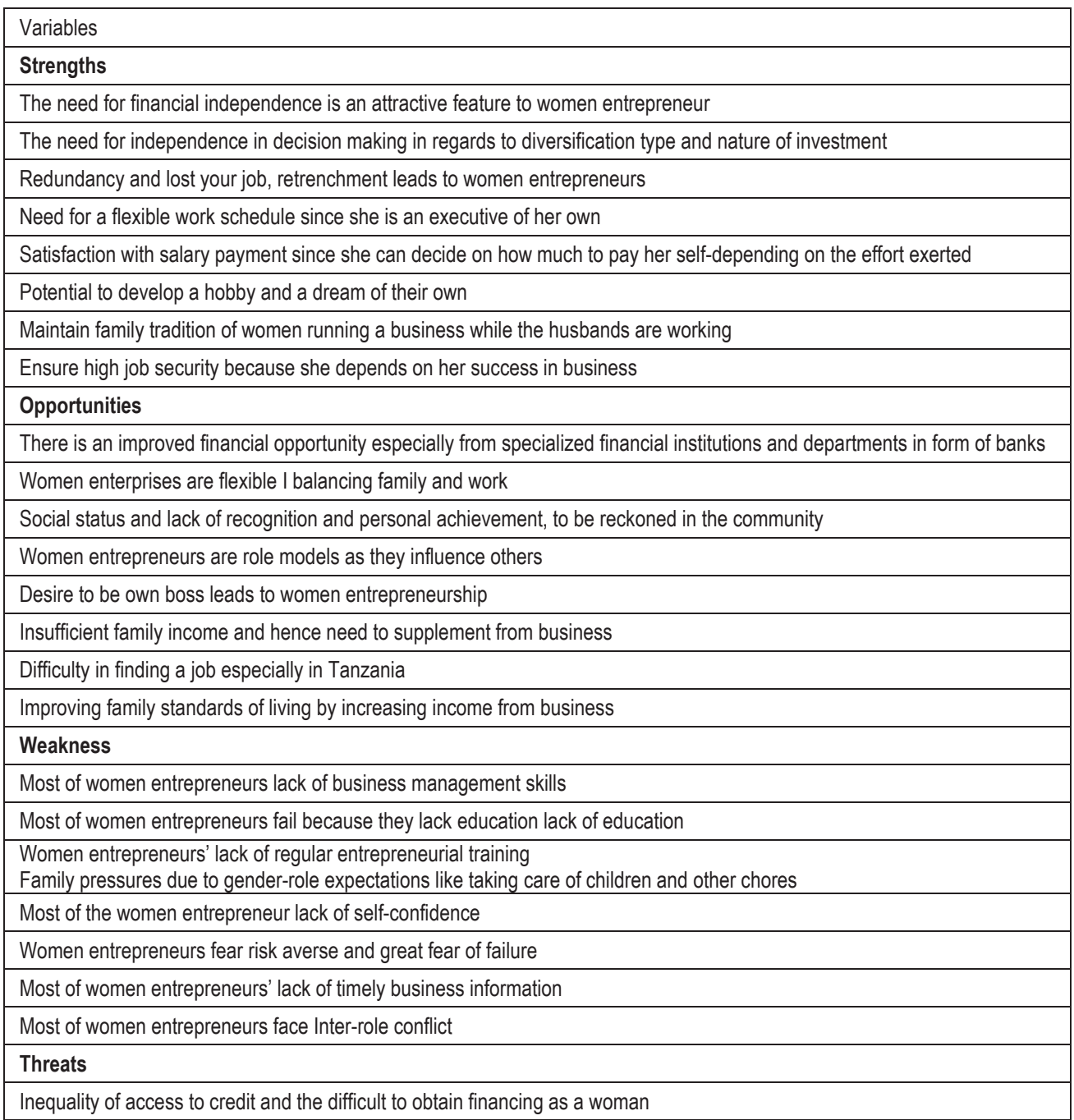




\begin{tabular}{|l|}
\hline Inhibiting laws and regulations, lower access to land, contractual rights- husband's consent or judge approval \\
\hline Socio-cultural environment and lack of respect from male community and stereotype \\
\hline Isolation from business network especially business owned by men \\
\hline Most of women entrepreneurs' lack of female role models in the society \\
\hline Most of women entrepreneurs have pressure of childcare in the family \\
\hline
\end{tabular}

\begin{tabular}{|c|c|c|c|c|c|}
\hline \multicolumn{6}{|l|}{ Correlations } \\
\hline & & Strength & opportunities & weakness & threats \\
\hline \multirow[t]{3}{*}{ Strength } & Pearson Correlation & 1 & & & \\
\hline & Sig. (2-tailed) & & & & \\
\hline & $\mathrm{N}$ & 132 & & & \\
\hline \multirow[t]{3}{*}{ Opportunities } & Pearson Correlation & $.245^{* *}$ & 1 & & \\
\hline & Sig. (2-tailed) & .005 & & & \\
\hline & $\mathrm{N}$ & 132 & 132 & & \\
\hline \multirow[t]{3}{*}{ Weakness } & Pearson Correlation & .089 & $.388^{* *}$ & 1 & \\
\hline & Sig. (2-tailed) & .309 & .000 & & \\
\hline & $\mathrm{N}$ & 132 & 132 & 132 & \\
\hline \multirow[t]{3}{*}{ Threats } & Pearson Correlation & .038 & $.217^{*}$ & $.421^{* *}$ & 1 \\
\hline & Sig. (2-tailed) & .667 & .012 & .000 & \\
\hline & $\mathrm{N}$ & 132 & 132 & 132 & 132 \\
\hline \multicolumn{5}{|c|}{${ }^{* \star}$. Correlation is significant at the 0.01 level (2-tailed). } & \\
\hline \multicolumn{4}{|c|}{${ }^{*}$. Correlation is significant at the 0.05 level (2-tailed). } & & \\
\hline
\end{tabular}

\section{Source field data( 2012)}

From the Pearson's Correlations table 1, it can be seen that the weakness and threats Pearson's correlation coefficient (r) equals $.421^{* *}$, indicating a strong relationship in terms of correlation. $p<.000$ and indicates that the coefficient is significantly different from 0 .We can conclude that there is correlation between weakness and threats. In particular, it seems that the more weakness the women entrepreneur's in Dar es salaam, the greater the threats in the operations of their enterprises $(r=.421, p<.000)$.

Considering the fact of Family pressures due to gender-role expectations like taking care of children and other chores, Most of women entrepreneurs face Inter-role conflict as weaknesses and Most of women entrepreneurs have pressure of childcare in the family,Socio-cultural environment and lack of respect from male community and stereotype, isolation from business network especially business owned by men are threats faced by women entrepreneurs, hence this affirms to the study conducted by Gibb (1993) social factors may involve personal background, family background, stage of career, early life experiences and growth environment. Hebert et al. (1997) suggest that in certain contexts women may be more strongly driven by social pressures. Kirk and Belovics (2006) summarized that women become entrepreneurs in order to balance work and family. Social networks have also been identified as one of the major factors that motivate women entrepreneurs (Gadar andYunus, 2009).

From table 1, it can be noted that the opportunities and weakness Pearson's correlation coefficient ( $r$ ) equals $.388^{* *}$, indicating a strong relationship in terms of correlation. $p<.000$ and indicates that the coefficient is significantly different from 0 .We can conclude that there is correlation between opportunities and weakness. In particular, it seems that the more opportunities the women entrepreneur's in Dar essalaam, the greater the weakness in the operations of their enterprises $(r=.388, p<.000)$. 
Family pressures due to gender-role expectations like taking care of children and other chores, most of women entrepreneurs face Inter-role conflict are some of the weakness and on the aspect of opportunities, Women enterprises are flexible in balancing family and work, Social status and lack of recognition and personal achievement, to be reckoned in the community, Women entrepreneurs are role models as they influence others, Desire to be own boss leads to women entrepreneurship, Insufficient family income and hence need to supplement from business, Difficulty in finding a job especially in Tanzania, Improving family standards of living by increasing income from business hence the study of Cromie (1987) found that in their motives whether or not to become an entrepreneur, women are less concerned with making money and often choose entrepreneurship as a result of career dissatisfaction. They also see entrepreneurship as a means of simultaneously satisfying their own career needs and those of their children and family. In addition the desire for greater flexibility, seeking challenges and escaping from organizational bureaucracy are also among the motivational factors that lead women to start up their own businesses (Lee andRogoff, 1997). According to studies done by Schwartz (1976), Scott (1986) and Hisrich (1986), major motivations for women to start a business were the need to achieve, the desire to control and be independent, the need for job satisfaction and economic necessity.

From table 1, it indicates that the strengths and opportunities Pearson's correlation coefficient ( $r$ ) equals $.245^{* *}$, indicating a strong relationship in terms of correlation. $p<0.05$.We can conclude that there is correlation between strengths and opportunities. In particular, it seems that the more strengths the women entrepreneur's in Dar es salaam, the more the opportunities are generated in the operations of their enterprises $(r=.245, p<0.05)$.

Redundancy and lost your job, retrenchment leads to women entrepreneurs, Ensure high job security because she depends on her success in business, Need for a flexible work schedule since she is an executive of her own are some of the strengths and opportunity like Desire to be own boss leads to women entrepreneurship.

Lee and Rogoff, (1997) confirms that the desire for greater flexibility, seeking challenges and escaping from organizational bureaucracy are also among the motivational factors that lead women to start up their own businesses.

From table1, it implies that the opportunities and threats Pearson's correlation coefficient ( $r$ ) equals .012 , which implies that there is a relationship in terms of correlation. $p<.000$ and indicates that the coefficient is significantly different from 0 .We can conclude that there is correlation between opportunities and threats. In particular, it seems that the more opportunities in the women entrepreneurship in Dar es salaam, the more the threats are like to arise in the daily operations of their enterprises $(r=.421, p<.000)$.

There is an improved financial opportunity especially from specialized financial institutions and departments in form of banks, Women enterprises are flexible I balancing family and work,inequality of access to credit and the difficult to obtain financing as a woman, there is a correlation since the entrepreneur they can get financial support to start and operate the enterprises.

From table 1, it can be noted that the strengths and weakness Pearson's correlation coefficient ( $r$ ) equals .089 , indicating that there is relationship in terms of correlation. $p<.309$ and indicates that the coefficient is significantly where the $(r)$ is lower than the $P$ value. We can conclude that there is no correlation between strengths and weakness on the women entrepreneur's in Dar essalaam in Tanzania.

There was no correlation considering the inter-role conflict and need for a flexible work schedule, maintaining family tradition of women running a business hence the data from the responds confirms.

From table 1, it can be noted that the strengths and threats Pearson's correlation coefficient (r) equals .038 , indicating that there is relationship in terms of correlation. $p<.667$ and indicates that the coefficient is significantly where the $(r)$ is lower than the $(P)$ value. We can conclude that there is no correlation between strengths and threats on the women entrepreneur's in Dar essalaam in Tanzania.

When a variable interacts with itself, the correlation will obviously be 1.00 . Which implies no significance is given in these cases.

\section{Conclusion}

From the field data we can conclude that there is a correlation between weakness and threats, opportunities and weakness, strengths and opportunities.There is weak correlation between opportunities and threats, strengths and threats.

A prerequisite for starting a firm is to have capital in terms of financial assets and in terms of relevant knowledge assets. Women's positions in society have led to a lack of assets in both these aspects. The constraints of family obligations make it harder for women to take on work on a full time basis and to engage in a career. This in turn 
decreases the range of possible work opportunities for women, leading to jobs in lower paid sectors. Being a part-time worker with low pay will not permit creating personal wealth.

Some major areas have been identified as potential or real problems for women when it comes to financing: women may be disadvantaged in raising the initial capital to start a new firm; collateral needed for external financing may be above the wealth level of most women and financing for an existing firm may be less available, because women are less likely than men to penetrate informal financial networks; The women entrepreneurs lack the proper awareness and relevant skills and experience to handle the business environment that is uncertain and guides entrepreneurs to thrive on chaos.

\section{Recommendations}

The government and Non-governmental organizations should open training programmesfor women entrepreneurs based on their needs. Finance be made available to enable them to access business development and other services.

Society and the community at large should be made aware of the needs of women entrepreneurs and specifically those with limited skills and the skilled ones. People should be made aware of their valuable contribution so that they might be more friendly and supportive towards women entrepreneurs.

\section{References}

Aldrich, H., and Zimmer, C. (1986).Entrepreneurship through social networks.In D. L Sexton,\& R. W. Smilor (Eds.).The Art and Science of Entrepreneurship: 3-24. Cambridge, Massachusetts: Ballinger Publishing Company.

Balakrishnan N, Lai CD. Continuous Bivariate Distributions. 2nd ed. New York: Springer; 2009.

Burt, R. S. (2000). The network entrepreneur. In R. Swedberg (Ed.), Entrepreneurship: TheSocial Science View: 281-307. Oxford, England: Oxford University Press.

Corty EW. Using and Interpreting Statistics: A Practical Text for the Health, Behavioral, and Social Sciences. St. Louis, MO: Mosby, Inc; 2007.

Deaux, K., and Lafrance, M. (1998).Gender.In D. T. Gilbert, S. T. Fiske and G. Lindzey (Eds.).The Handbook of Social Psychology, Vol. 1: 788-827. Boston: McGraw Hill.

De Groot, T. U. (2001). Women Entrepreneurship Development in Selected African Countries.Vienna, Austria: UNIDO.

Granovetter, M. S. (1973). The strength of weak ties.American Journal of Sociology, 78(6):1360- 1380.

Cromie, S. 1987. Motivations of aspiring male and female entrepreneurs. Journal of Occupational Behaviour, 8(3), 251-261.

Gibb, A. (1993). Small Business Development In Central And Eastern Europe-Opportunity For A Rethink?.Journal of Business Venturing, Vol.8, pp. 461-86

Hisrich, R. (1986). The woman entrepreneur: Characteristics, skills, problems, and prescriptions for success.

Karim, N. A. (2000). Jobs, Gender and Small Enterprises in Bangladesh: Factor AffectingWomen Entrepreneurs in Small and Cottage Industries in Bangladesh. Geneva: ILO.

L. Sexton, and K. H. Vesper (Eds.). Encylopedia of Entrepreneurship: 72-90. Engelwoods Cliffs,NJ: Prentice-Hall.

OECD (2004). $2^{\text {nd }}$ Conference of ministers responsible for small and medium-sized enterprises(SMES): Women's entrepreneurship: issues and policies: - Istanbul, Turkey, June 2004

Schwartz, E. (1976). Entrepreneurship: A New Female Frontier. Journal of Contemporary Business, Vol. 5 (1), pp. 47-76.

Scott, C.E. (1986). Why More Women Are Becoming Entrepreneurs. Journal of Small Business Management.Vol. 24 (4), pp. 3744

Storey, D. J. (1994).Understanding the Small Business Sector. London: Routledge.

Sida (2009). Women's Economic Empowerment: Scope for Sida's Engagement, Sida Working Paper, December 30, Publication series: Women's Economic Empoverment

Spring, A. (2009). "African Women in the Entrepreneurial Landscape: Reconsidering the Formal and Informal Sectors". Journal of African Business, 10:11-30 
